\title{
Critical role of glycogen synthase kinase-3ß in regulating the avian heterophil response to Salmonella enterica serovar Enteritidis
}

\author{
Michael H. Kogut ${ }^{1}{ }^{*}$, Christina L. Swaggerty ${ }^{1}$, Hsin-I Chiang ${ }^{2}$, Kenneth J. Genovese ${ }^{1}$, Haiqi He ${ }^{1}$, \\ Huaijun Zhou ${ }^{3}$ and Ryan J. Arsenault ${ }^{1}$ \\ ${ }^{1}$ Southern Plains Agricultural Research Center, Agricultural Research Service, United States Department of Agriculture, College Station, TX, USA \\ 2 Department of Animal Sciences, National Chung Hsing University, Taichung, Taiwan \\ ${ }^{3}$ Department of Animal Science, University of California Davis, Davis, CA, USA
}

\section{Edited by:}

Maureen T. Long, University of Florida College of Veterinary Medicine, USA

\section{Reviewed by:}

Vivek A. Kuttappan, University of Arkansas, USA

Amanda Wolfenden, University of Arkansas, USA

${ }^{*}$ Correspondence:

Michael H. Kogut, Southern Plains Agricultural Research Center.

Agricultural Research Service, United States Department of Agriculture, 2881 F\&B Road, College Station, TX 77845, USA

e-mail:mike.kogut@ars.usda.gov
A microarray-assisted gene expression screen of chicken heterophils revealed glycogen

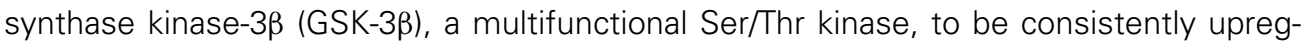
ulated 30-180 min following stimulation with Salmonella enterica serovar Enteritidis (S. Enteritidis). The present study was designed to delineate the role of GSK-3 $\beta$ in regulating the innate function of chicken heterophils in response to $S$. Enteritidis exposure. Using a

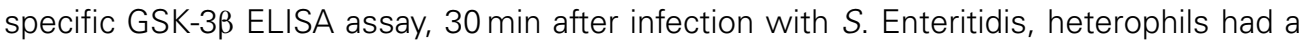
significant decrease $(p \leq 0.05)$ in total GSK-3 $\beta$, but a significant increase $(p \leq 0.05)$ in phosphorylated GSK-3 $\beta$ (Ser9). By 60 min post-infection, there was no difference in the amount of phosphorylated GSK-3 $\beta$ (Ser9) in either the uninfected and infected heterophils. S. Enteritidis interaction with heterophils alters GSK-3 $\beta$ activity by stimulating phosphorylation at Ser9 and that peaks by 30 min post-infection. Further, inhibition of GSK3 $\beta$ with lithium chloride resulted in a significant decrease $(p \leq 0.05)$ in NF-KB activation and expression of IL-6, but induces a significant increase $(p \leq 0.05)$ in the expression of the anti-inflammatory cytokine, IL-10. Using a phospho-specific antibody array confirmed the phosphorylation of GSK-3 $\beta$ (Ser9) as well as the phosphorylation of the downstream cytokine-activated intracellular signaling pathway involved in stimulating immune responses, $I_{\kappa} B$, the $I_{\kappa} B$ subunit IKK- $\beta$, and the NF-KB subunits p105, p65, and c-Rel. Our data revealed that the phosphorylation of GSK-3 $\beta$ (Ser9) is responsible for inducing and controlling an innate response to the bacteria. Our findings suggest that the repression of GSK-3 activity is beneficial to the host cell and may act as a target for treatment in controlling intestinal colonization in chickens. Further experiments will define the in vivo modulation of GSK-3 as a potential alternative to antibiotics in salmonella and other intestinal bacterial infections.

Keywords: glycogen synthase kinase-3ß, chickens, heterophils, Salmonella, innate immunity

\section{INTRODUCTION}

Polymorphonuclear leukocytes (PMNs) are vital cellular components of innate immunity and function by killing pathogenic microbes following phagocytosis. The primary PMN in poultry is the heterophil, the avian equivalent to the mammalian neutrophil. Like the neutrophil, heterophils provide a rapid deployment of the effector arm of the bird's innate immune system. Heterophils are rapidly recruited following infection to the site of acute infection. In addition to their well-established role as microbial killers, accumulating evidence shows that heterophils can play an immunoregulatory role (1).

Non-typhoid Salmonella infections in poultry induce a rapid acute inflammatory response characterized by an influx of heterophils within hours that, for the most part, restricts infection to the intestine, while activating the innate immune response (2-4). Reducing the number of circulating heterophils significantly increases the susceptibility of young chickens to extra-intestinal infection by Salmonella enterica serovar
Enteritidis (S. Enteritidis) indicating a key effector role for peripheral blood heterophils in controlling acute $S$. Enteritidis infections in poultry (1). Unlike macrophages where Salmonella are able to infect and persist, Salmonella have not been shown to survive the within heterophils. However, the mechanisms that regulate this antibacterial activity are not understood, although degranulation is considered especially important.

The serine/threonine kinase, glycogen synthase kinase $3 \beta$ (GSK3 $\beta$ ), plays a pivotal role in regulating the inflammatory response of macrophages and neutrophils in mammals $(5,6)$. GSK3 $\beta$ is unique among kinases in that it is constitutively active in resting cells and its activity can be inhibited by serine phosphorylation by a variety of cellular functions including apoptosis, glycogen metabolism, microtubule function, and cell motility ( 7 , 8). However, it is the enzyme's ability to regulate elements of both the innate and acquired immune system that has generated the most recent interest $(5,9)$. 
In a recent study involving the whole chicken genome microarray analysis of $S$. Enteritidis-stimulated heterophils, we observed a consistent upregulation of GSK-3 $\beta$ isoform mRNA expression $(10,11)$. The present study was designed to delineate the role of GSK-3 $\beta$ in regulating the innate function of chicken heterophils in response to $S$. Enteritidis exposure.

\section{MATERIALS AND METHODS EXPERIMENTAL ANIMALS}

One-day-old Cobb $\times$ Ross straight-run broiler chicks were obtained from a local commercial hatchery and were placed on new pine shavings. Birds were provided water and a balanced, unmedicated ration ad libitum. The feed ration contained or exceeded the levels of critical nutrients recommended by the National Research Council (12). All animal experiments were conducted according to the rules and regulations established by the United States Department of Agriculture Animal Care Use Committee and overseen by an attending staff veterinarian.

\section{BACTERIA}

A poultry isolate of Salmonella enterica serovar Enteritidis ( $S$. Enteritidis) (\#97-11771) was obtained from the National Veterinary Services Laboratory (Ames, IA, USA). S. Enteritidis was cultured in tryptic soy broth (Difco Laboratories, Becton Dickinson Co., Sparks, MD, USA) overnight at $41^{\circ} \mathrm{C}$. Stock $S$. Enteritidis $\left[1 \times 10^{9}\right.$ colony forming units $\left.(\mathrm{cfu}) / \mathrm{ml}\right]$ was prepared as previously described (13).

\section{HETEROPHIL ISOLATION}

Heterophils were isolated from the peripheral blood of 100 chickens per line 6 days post-hatch. Following blood collection, heterophils were isolated as previously described (14). Briefly, blood from chickens was collected in vacutainer tubes containing disodium ethylenediaminetetraacetic acid (EDTA) (BD vacutainer, Franklin Lakes, NJ, USA) and mixed thoroughly. The blood and EDTA for each line was pooled and diluted 1:1 with RPMI 1640 media containing $1 \%$ methylcellulose and centrifuged at $40 \mathrm{~g}$ for $15 \mathrm{~min}$ at $4^{\circ} \mathrm{C}$. The supernatant was transferred to a new conical tube and diluted with $\mathrm{Ca}^{2+}$ - and $\mathrm{Mg}^{2+}$-free Hanks balanced salt solution (1:1), layered onto discontinuous Histopaque ${ }^{\circledR}$ gradients (specific gravity 1.077 over 1.119) and centrifuged at $190 \mathrm{~g}$ for $1 \mathrm{~h}$ at $4^{\circ} \mathrm{C}$. The Histopaque ${ }^{\circledR}$ layers were collected, washed with RPMI 1640 (1:1), and pelleted at $485 g$ for $15 \mathrm{~min}$ at $4^{\circ} \mathrm{C}$. The cells were then re-suspended in fresh RPMI 1640, counted on a hemacytometer, and diluted to $1 \times 10^{7} / \mathrm{ml}$ in RPMI. All tissue culture reagents and chemicals obtained from Sigma Chemical Company, St. Louis, MO, USA, unless noted otherwise.

\section{TOTAL RNA ISOLATION}

Heterophils $\left(1 \times 10^{7}\right)$ were treated with $300 \mu$ l RPMI or SE, for 30 and $60 \mathrm{~min}$ at $39^{\circ} \mathrm{C}$ on a rotary shaker at the ratio of multiplicity of infection $=20$. Treated heterophils were pelleted, washed with RPMI $\left(485 \times g\right.$ for $15 \mathrm{~min}$ at $\left.4^{\circ} \mathrm{C}\right)$, the supernatant discarded, the cells re-suspended in lysis buffer (Qiagen RNeasy mini RNA extraction kit, Qiagen Inc., Valencia, CA, USA), and frozen. The lysed cells were transferred to QIAshredder homogenizer columns and centrifuged for $2 \mathrm{~min}$ at $\geq 8000 \times g$. Total RNA was extracted from the homogenized lysate according to the manufacturer's instructions, eluted with $50 \mu \mathrm{l}$ RNase-free water and stored at $-80^{\circ} \mathrm{C}$. RNA was quantified using a spectrophotometer (NanoDrop Products, Wilmington, DE, USA).

\section{MICROARRAY EXPERIMENT DESIGN}

A dual color, balanced design was used to provide comparisons between uninfected and infected heterophils. Four biological replicates were conducted in each comparison, and the dye balance was used throughout in order to prevent the dye bias during the sample labeling.

\section{Labeling and hybridization}

The integrity of total RNA samples was confirmed using Agilent Bioanalyzer 2100 Lab-on-chip system (Agilent Technologies, Palo Alto, CA, USA). Five hundred nanograms (ng) of total RNA were reverse-transcribed to cDNA during which a $\mathrm{T} 7$ sequence was introduced into cDNA. T7 RNA polymerase-driven RNA synthesis was used for the preparation and labeling of RNA with Cy3 (or Cy5) dye. The fluorescent cRNA probes were purified using Qiagen RNeasy Mini Kit (Qiagen Inc., Valencia, CA, USA), and an equal amount ( $825 \mathrm{ng}$ ) of $\mathrm{Cy} 3$ and Cy5 labeled cRNA probes were hybridized on a $44 \mathrm{~K}$ chicken Agilent array. The hybridized slides were washed using a commercial kit package (Agilent Technologies, Palo Alto, CA, USA) and then scanned using Genepix 4100A scanner (Molecular Devices Corporation, Sunnyvale, CA, USA) with the tolerance of saturation setting of $0.005 \%$.

\section{Microarray data collection and analysis}

For each channel, the median of the signal intensity and local background values were used. A locally weighted linear regression (LOWESS) normalization was applied to remove signal intensitydependent dye bias for each array using R program. The normalized data were analyzed using commercial SAS 9.1.3 program (SAS Institute Inc., Cary, NC, USA) with mixed model analysis. The mixed model used to identify significantly differentially expressed genes was:

$$
Y_{\mathrm{ijklm}}=\mu+T_{\mathrm{i}}+L_{\mathrm{j}}+D_{\mathrm{k}}+S_{\mathrm{l}}+T \times L_{\mathrm{ij}}+e_{\mathrm{ijklm}}
$$

where $Y_{\mathrm{ijklm}}$ represents each normalized signal intensity, $\mu$ is an overall mean value, $T_{\mathrm{i}}$ is the main effect of treatment (SE infection), $L_{\mathrm{j}}$ is the main effect of heterophil, $D_{\mathrm{k}}$ is the main effect of dye, $S_{1}$ is the random effect of slide $1, T L_{\mathrm{ij}}$ is the interaction between treatment and heterophils, and $e_{\mathrm{ijklm}}$ is a stochastic error (assumed to be normally distributed with mean 0 and variance $\sigma^{2}$ ). An approximate $F$ test on least-square means was used to estimate the significance of difference for each gene in each comparison where $p<0.001$ was considered to be statistically different. The false discovery rate ( $Q$ value) was calculated for each $p$-value using R program according to the Storey and Tibshirani method (15).

\section{GSK-3 $\beta$ ELISA ASSAY}

Total and phosphorylated GSK-3 $\beta$ were measured by a solid phase sandwich ELISA kits (Invitrogen, Camarillo, CA, USA). The GSK$3 \beta$ (total) ELISA kit quantifies GSK-3 $\beta$ independently of phosphorylation status and allows normalization of phosphorylated 
GSK-3 $\beta$ to total GSK-3 $\beta$. Preparation of cell extracts was done according to the manufacturer's instructions. Total amount of GSK-3 $\beta$ (Ser9) was determined using a standard curve.

\section{ANTIBODY ARRAY}

The antibody array assay kit was procured from Full Moon BioSystems (Sunnyvale, CA, USA). This technique was used as an alternative to procuring phospho-specific antibodies individually and performing several western blot assays. The protocol was carried out as per manufacturer's instructions with the following alteration to the homogenization step: instead of using the bead and vortex homogenization indicated in the kit, the hand-held Qiagen TissueRuptor was used.

\section{Data analysis for antibody array}

Data normalization and PCA analysis was performed for both the peptide and antibody microarrays as per Li et al. (16). This custom analysis method was designed specifically for analysis of phosphorylation microarray data and allowed for a statistically robust analysis of the phosphorylation events being measured. Geneontology (GO) and Kyoto Encyclopedia of Genes and Genomes (KEGG) pathway analysis was performed by uploading the statistically significant peptide lists to the Search Tool for the Retrieval of Interacting Genes (STRING) (17).

\section{INHIBITOR TREATMENTS}

Heterophils isolated as described above were aliquoted into sterile 2-ml Eppendorf tubes $\left(1 \times 10^{7}\right.$ cells $\left./ \mathrm{ml}\right)$ where they were preincubated with the appropriate concentrations of the various inhibitors for $30 \mathrm{~min}$ at room temperature. Following these preincubations, the heterophils were then stimulated with $S$. Enteritidis $\left(10^{9} \mathrm{cfu} / \mathrm{ml}\right)$ for $1 \mathrm{~h}$ at $41^{\circ} \mathrm{C}$. The following inhibitors and optimal concentrations were used in these studies: BAY 11-7086

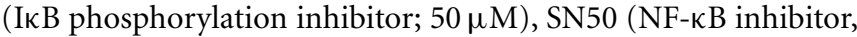
$100 \mu \mathrm{g} / \mathrm{ml}$ ), and lithium chloride (LiCl, GSK3 inhibitor, $10 \mathrm{mM}$ ) as previously determined (18). Based on our previous experiments, the optimal concentrations used in the present experiments had no toxic effects on the avian heterophils.

\section{QUANTITATIVE REAL-TIME PCR}

Primer and probe sets for the cytokines and 28S rRNA were designed using the Primer Express software program (Applied Biosystems, Foster City, CA, USA). Cytokine and chemokine mRNA expression was quantitated using a well-described method. Primers and probes for cytokines, chemokines, and 28S rRNAspecific amplification have been described $(19,20)$ and are provided in Table 1. All primers and probes were purchased from Integrated DNA technologies (San Diego, CA, USA). The qRTPCR was performed using the TaqMan fast universal PCR master mix and one-step RT-PCR master mix reagents [(19,20); Applied Biosystems]. Amplification and detection of specific products were performed using the Applied Biosystems 7500 Fast real-time PCR system with the following cycle profile: one cycle of $48^{\circ} \mathrm{C}$ for $30 \mathrm{~min}$ and $95^{\circ} \mathrm{C}$ for $20 \mathrm{~s}$ and 40 cycles of $95^{\circ} \mathrm{C}$ for $3 \mathrm{~s}$ and $60^{\circ} \mathrm{C}$ for $30 \mathrm{~s}$. Quantification was based on the increased fluorescence detected by the 7500 Fast sequence detection system due to hydrolysis of the target-specific probes by the $5=$ nuclease activity of the $r$ th DNA polymerase during PCR amplification. Normalization was carried out against $28 \mathrm{~S}$ rRNA, which was used as a housekeeping gene. To correct for differences in RNA levels between samples within the experiment, the correction factor for each sample was calculated by dividing the mean threshold cycle $(C T)$ value for $28 \mathrm{~S}$ rRNAspecific product for each sample by the overall mean $C T$ value for the $28 \mathrm{~S}$ rRNA-specific product from all samples. The corrected cytokine mean was calculated as follow: (average of each replicate $\times$ cytokine slope $) /(28 \mathrm{~S}$ slope $\times 28 \mathrm{~S}$ correction factor $)$. Fold

Table 1 | GSK-3 $\beta$ pathway genes from DNA microarray

\begin{tabular}{|c|c|c|c|c|c|}
\hline Gene & Description & $\begin{array}{l}30^{\prime} \text {-fold } \\
\text { change }\end{array}$ & $p$ value & $\begin{array}{l}60^{\prime} \text {-fold } \\
\text { change }\end{array}$ & $p$ value \\
\hline $\mathrm{PI}-3 \mathrm{~K}$ & Phosphatidylinositide 3-kinase & NS & - & NS & - \\
\hline Akt & Protein kinase B; Serine/threonine protein kinase & NS & - & NS & - \\
\hline S6 ribosomal protein & & NS & - & NS & - \\
\hline Casein kinase & & 1.65 & 0.00012 & 3.48 & $1.95 \times 10^{-10}$ \\
\hline Axin-1 & & 3.60 & $3.9 \times 10^{-6}$ & 7.29 & $2.74 \times 10^{-9}$ \\
\hline GSK-3 $\beta$ & Glycogen synthase kinase-3 $\beta$ & 3.01 & $1.72 \times 10^{-8}$ & 2.69 & $5.87 \times 10^{-8}$ \\
\hline CREB & CAMP response element-binding protein & NS & - & NS & - \\
\hline$I_{\kappa} B$ & Inhibitor of NF-кB & 3.79 & $9.11 \times 10^{-11}$ & 4.46 & $2.13 \times 10^{-11}$ \\
\hline$N F-\kappa B$ & Nuclear factor kappa-light-chain-enhancer of activated B cells & 3.34 & $5.8 \times 10^{-8}$ & 4.59 & $3.74 \times 10^{-9}$ \\
\hline IL-10 & Interleukin-10 & NS & - & NS & - \\
\hline IL-12 p40 & Interleukin-12 & $2.92 \times 10$ & $2 \times 10^{-5}$ & 28.46 & $7.89 \times 10^{-11}$ \\
\hline IL-I $\beta$ & Interleukin-1 $\beta$ & 16.22 & $2.59 \times 10^{-12}$ & 21.04 & $5.62 \times 10^{-13}$ \\
\hline IL-6 & Interleukin-6 & 9.87 & $2.39 \times 10^{-7}$ & 22.73 & $9.84 \times 10^{-9}$ \\
\hline B-catenin & & 2.77 & $2.03 \times 10^{-5}$ & 2.23 & $2.55 \times 10^{-5}$ \\
\hline
\end{tabular}

NS, no statistical differences between uninfected and infected heterophils at the time point assayed.

Positive values in fold change mean that genes have a higher expression in infected heterophils.

Negative values in fold change mean genes have a higher expression in uninfected heterophils. 
changes in mRNA levels were calculated from mean $40 \mathrm{CT}$ values

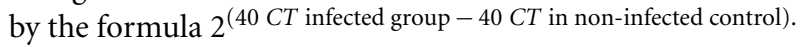

\section{DEGRANULATION ASSAY}

Degranulation was detected by quantifying the amount of $\beta$-Dglucuronidase activity in the culture medium following stimulation of the heterophils with $S$. Enteritidis. Heterophils $\left(8 \times 10^{6}\right)$ were incubated with either RPMI 1640 medium alone or the GSK inhibitor, $\mathrm{LiCl}$ at room temperature for 30 or $60 \mathrm{~min}$. The heterophils were then stimulated with various MOI of $S$. Enteritidis $(1,10$, or 100$)$ for $1 \mathrm{~h}$ at $41^{\circ} \mathrm{C}$. The reaction was stopped by transferring the tubes containing the cells to an ice bath for 5-10 $\mathrm{min}$. The cells were then centrifuged at $250 \mathrm{~g}$ for $10 \mathrm{~min}$ at $4^{\circ} \mathrm{C}$. The supernatants were then removed and used for the assay. A $25 \mu \mathrm{l}$ aliquot of each supernatant was added to quadruplicate wells in a nontreated, black CoStar flat-bottom ELISA plate and incubated with $50 \mu \mathrm{l}$ of freshly prepared substrate (10 mM 4-methylumbelliferyl$\beta$-D-glucuronidase, $0.1 \%$ Triton $\mathrm{X}-100$ in $0.1 \mathrm{M}$ sodium acetate buffer) for $4 \mathrm{~h}$ at $41^{\circ} \mathrm{C}$. The reaction was stopped by adding $200 \mu \mathrm{l}$ of stop solution (0.05M glycine and 5 mM EDTA; $\mathrm{pH} 10.4)$ to each well. Liberated 4-methylumbelliferone was measured fluorimetrically (excitation wavelength of $355 \mathrm{~nm}$ and an emission wavelength of $460 \mathrm{~nm}$ ) with a GENios Plus Fluorescence Microplate Reader (TECAN US Inc., Research Triangle Park, NC, USA). These values were converted to micromoles of 4-methylumbelliferone generated using a standard curve of known concentrations.

\section{NF- $\kappa$ B ANALYSIS}

The ELISA-based Trans-Am transcription factor kit (Active Motif, Carlsbad, CA, USA) was used to detect and quantify NF- $\kappa$ B activation. This kit uses a patented technology to attach oligonucleotides containing an NF- $\kappa \mathrm{B}$ binding consensus sequence $\left(5^{\prime}-\right.$ GGGACTTTCC-3' $)$ to a 96-well plate according to the transcription factors analyzed (18-20). The active forms of the subunits for NF-кB (p65, p52, p50, c-Rel, RelB) in whole cell extracts can be detected using specific antibodies for epitopes that are accessible only when the nuclear factors are activated and bound to their target DNA. Preparation of cell extract was done according to the manufacturer's instructions. The specificity of the assays was checked by measuring the ability of soluble wild type or mutated NF- $\mathrm{B}$ oligonucleotides to inhibit binding. The results are expressed as specific binding (absorbance measured in the presence of the mutated oligonucleotides minus that measured in the presence of the wild type oligonucleotides) according to the manufacturer's instructions.

\section{STATISTICAL ANALYSIS}

The anti-coagulated blood from 100 chickens was pooled and the peripheral blood heterophils and monocytes were isolated from each treatment group as described above. Each assay was conducted four times over a 2-month period with pooled cells (heterophils pooled from 100 chickens for each preparation, i.e., 400 chickens in total were used as cell donors). At least three replicates were conducted for each assay with the cells from each pool of chickens. The data from these four repeated experiments were pooled for presentation and statistical analysis.
The mean and standard error of the mean were calculated for each of the treatment groups. Differences between the noninfected and $S$. Enteritidis-infected heterophils were determined by analysis of variance. Significant differences were further separated using Duncan's multiple range test. The data obtained from the $S$. Enteritidis-infected heterophils were compared to non-stimulated control cells (ANOVA). All statistical analysis was conducted with SigmaStat 3.10 software (Systal Software, Point Richmond, CA, USA).

\section{RESULTS}

\section{DNA MICROARRAY}

Concentrating on the canonical GSK-3 pathway from the chicken whole genome array, we found a significant upregulation in the expression of Axin-1, GSK-3 $\beta$, and $\beta$-catenin in the heterophils 30-60 min after infection with $S$. Enteritidis (Table 1). Axin-1, GSK-3 $\beta$, and $\beta$-catenin form an intracellular complex that can regulate multiple signaling pathways involving inflammation (2123). Further, $S$. Enteritidis infection of the heterophils induced a significant upregulation of $\mathrm{I} \kappa \mathrm{B}, \mathrm{NF}-\kappa \mathrm{B}$, and mRNA of the proinflammatory cytokines IL-1 $\beta$, IL-6, and IL-12 p40 (Table 1). We found no effects on the mRNA expression of the upstream regulators of GSK-3, PI-3K and Akt, or in the expression of the anti-inflammatory cytokine, IL-10.

\section{S. ENTERITIDIS MODIFICATION OF GSK-3 $\beta$ PHOSPHORYLATION}

Within 30 min after infection with $S$. Enteritidis, heterophils had a significant $(p \leq 0.05)$ decrease in total GSK-3 $\beta$ (Figure 1A). By 60 min after infection, the amount of total GSK-3 $\beta$ was reversed where significantly $(p \leq 0.05)$ more total GSK-3 $\beta$ was found in the infected heterophils compared to the uninfected control cells. However, infection of the heterophils with $S$. Enteritidis significantly $(p \leq 0.05)$ increased phosphorylated GSK-3 $\beta$ (Ser9) within $30 \mathrm{~min}$ (Figure 1B). By $60 \mathrm{~min}$ post-infection, there was no difference in the amount of phosphorylated GSK-3 $\beta$ (Ser9) in either the uninfected and infected heterophils. These data suggest that $S$. Enteritidis interaction with heterophils alters GSK-3 $\beta$ activity by stimulating phosphorylation at Ser9 within 30 min post-infection.

\section{ROLE OF GSK-3 $\beta$ IN CYTOKINE mRNA EXPRESSION IN HETEROPHILS INFECTED WITH $S$. ENTERITIDIS}

Stimulation of heterophils with $S$. Enteritidis resulted in increased transcription of the pro-inflammatory cytokine IL-6 (Figure 2A). The expression of IL- 6 was significantly $(p \leq 0.01)$ decreased in $S$. Enteritidis-stimulated heterophils pretreated with the specific GSK-3 $\beta$ inhibitor LiCl. Conversely, stimulation of the heterophils with $S$. Enteritidis induced a very limited expression of the antiinflammatory cytokine, IL-10 (Figure 2B). However, inhibition of GSK-3 $\beta$ by $\mathrm{LiCl}$ resulted in a significant $(p \leq 0.01)$ increase in IL-10 mRNA transcription of heterophils stimulated with $S$. Enteritidis. These data point to the regulation of cytokine mRNA expression in heterophils stimulated with $S$. Enteritidis. It should be noted that heterophil viability was not affected by treatment with $\mathrm{LiCl}$ (data not shown). Likewise, treatment of the bacteria with $\mathrm{LiCl}$ for $1 \mathrm{~h}$ had no effect on growth or viability (data not shown). 


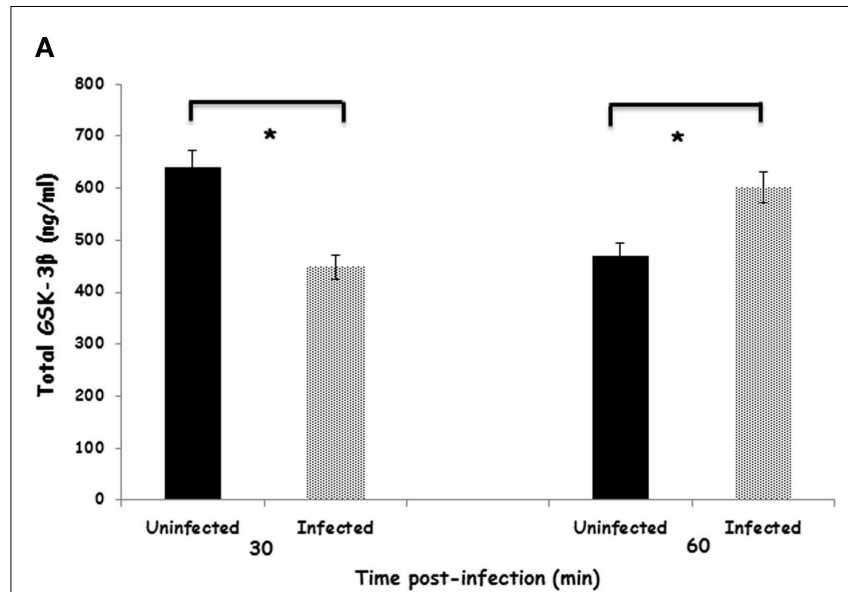

FIGURE 1 | Effect of $\boldsymbol{S}$. Enteritidis infection on GSK-3 $\beta$ activity in avian heterophils. (A) Total GSK-3 $\beta$ activity in avian heterophils stimulated with S. Enteritidis or non-infected for 30 and $60 \mathrm{~min}$. (B) Phosphorylated-GSK-3 $\beta$

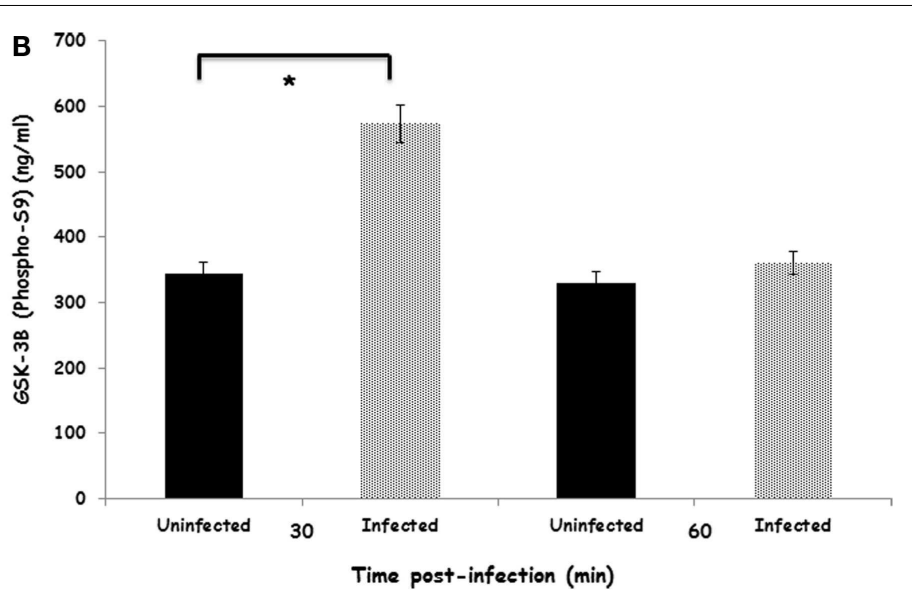

(Sr9) activity in avian heterophils after 30 and 60 min stimulation with $S$. Enteritidis. Data presented as mean \pm SEM from three separate experiments. ${ }^{*} p \leq 0.01$.

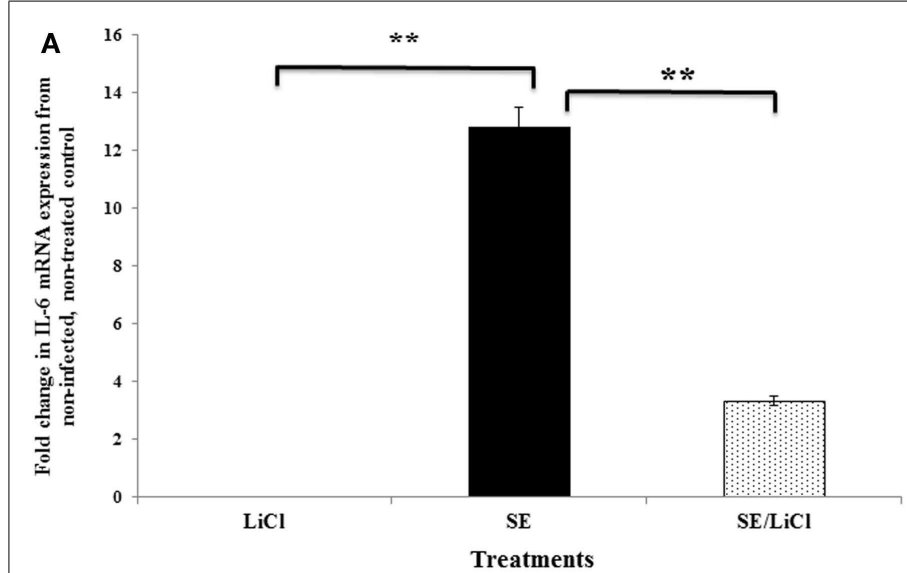

FIGURE 2 | Inhibition of GSK-3 $\beta$ differentially regulates pro- and anti-inflammatory cytokine mRNA expression by avian heterophils. Heterophils were pre-incubated with $\mathrm{LiCl}$ for $1 \mathrm{~h}$ and then stimulated with $S$. Enteritidis $(\mathrm{MOI}=100$ ) for 30 and $60 \mathrm{~min}$. The expression of cytokine mRNA was determined by quantitative RT-PCR. Data represent the fold

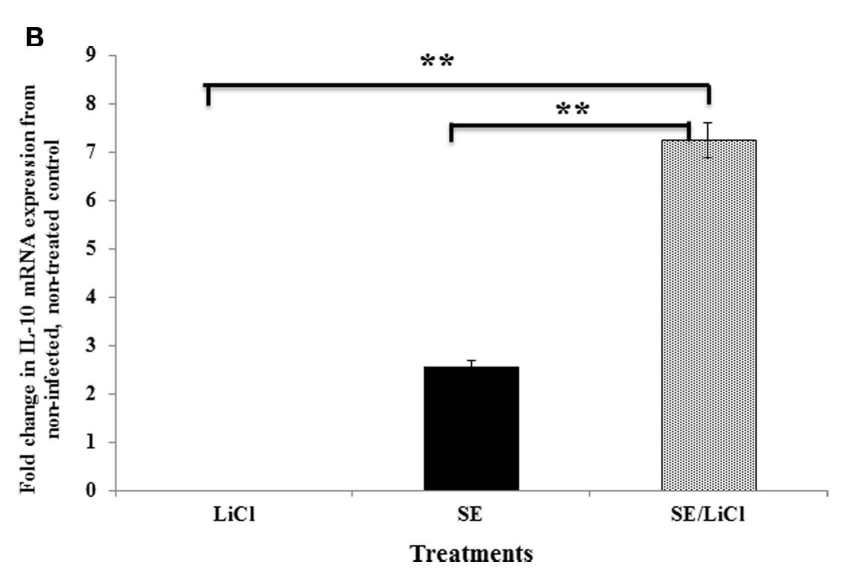

change in mRNA expression in heterophils from infected and/or $\mathrm{LiCl}$-treated groups when compared to the mRNA expression from the non-infected, untreated control heterophils. Data represent the mean \pm SEM from three separate experiments. ${ }^{*} p \leq 0.01$. (A) Expression of IL-6. (B) Expression of IL-10.

\section{ROLE OF GSK-3 $\beta$ IN $S$. ENTERITIDIS ACTIVATION OF NF-кB}

To better understand the mechanisms responsible for the effects of GSK-3 $\beta$ on $S$. Enteritidis-induced cytokine mRNA expression, we assessed the activation of NF- $\kappa \mathrm{B}$ through the use of the Trans-AM assay of the c-Rel, RelB, and p50 subunits (Figures 3A-C, respectively). We confirmed that stimulation of the avian heterophils with $S$. Enteritidis significantly $(p \leq 0.01)$ activated the nuclear $c-$ Rel, RelB, and p50 subunits of NF- $\kappa$ B that we previously reported (18). To validate the NF- $\kappa B$ subunit activation, we treated the heterophils with either the specific NF- $\kappa$ B inhibitor BAY 11-7086 or the cell-permeable NF- $\kappa$ B inhibitor SN50 and found a total inhibition of activation of each NF- $\kappa$ B subunit ( $p \leq 0.01$; Figures $3 \mathrm{~A}-\mathrm{C}$ ).

To assess the functional role of GSK- $3 \beta$ on $S$. Enteritidismediated activation of NF- $\kappa \mathrm{B}$, heterophils were treated with the GSK-3 $\beta$ inhibitor LiCl for 30 or 60 min before infection. Inhibition of GSK-3 $\beta$ significantly $(p \leq 0.01)$ decreased activation of each of the NF- $\kappa$ B subunits (Figures 3A-C). These data imply that GSK$3 \beta$ regulated $S$. Enteritidis-induced cytokine mRNA expression by activating NF- $\kappa \mathrm{B}$.

\section{ANTIBODY ARRAY}

Standard methodology for validating the phosphorylation of protein is the use of phospho-specific antibodies. Normally, western blots using antibodies for specific phosphorylation events are performed to confirm the individual phosphorylation events. We chose a variation of this standard validation process by employing an antibody microarray containing both pan-specific and phospho-specific antibodies. Despite the scarcity of chickenspecific antibodies, the key proteins of interest were relatively well conserved between human beings and chickens, giving us 


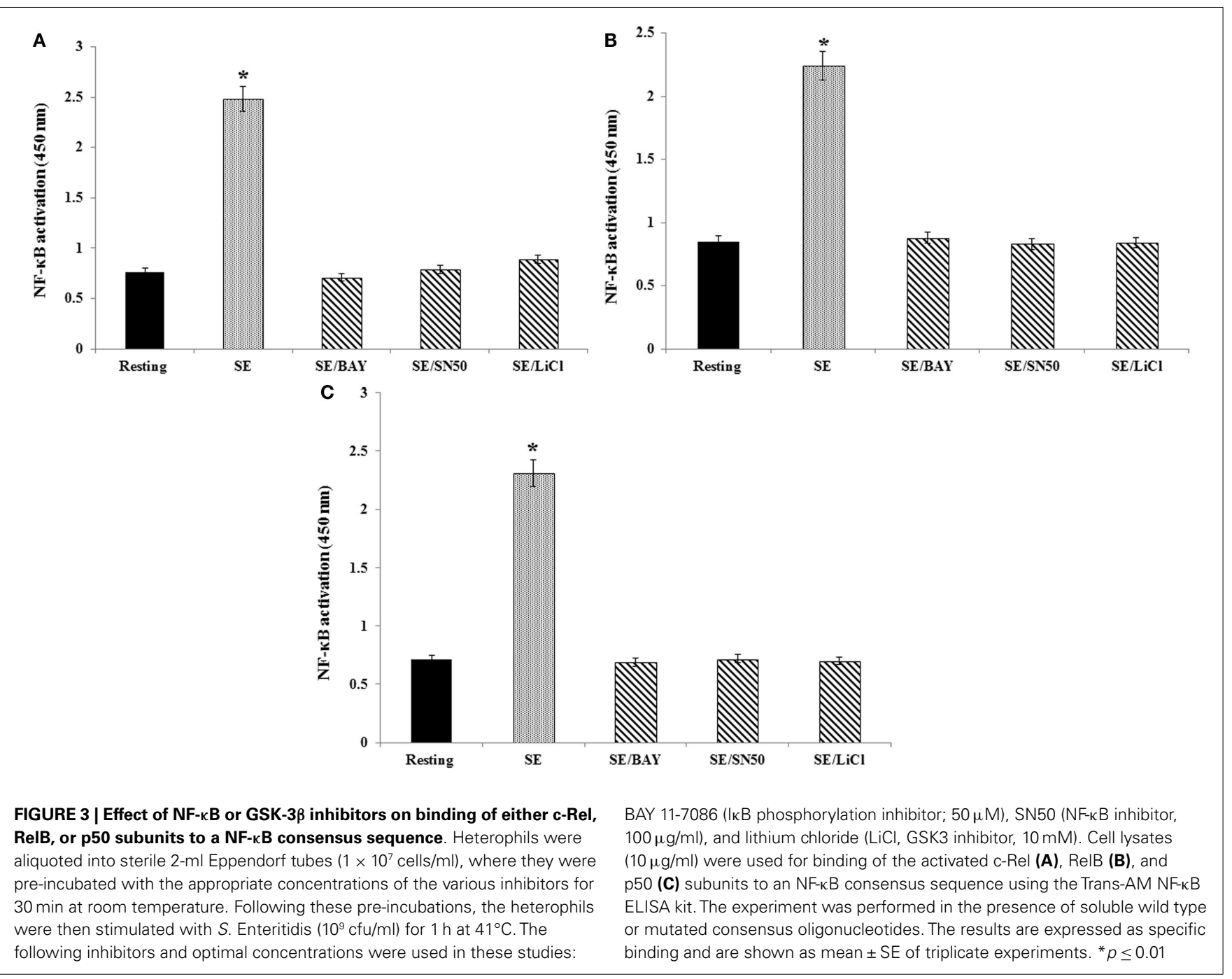

confidence that we would observe significant cross-reactivity from the antibodies.

We have previously shown that stimulation of heterophils with $S$. Enteritidis resulted in increased cellular signaling of PI-3K and Akt (24-26). Using a phospho-specific antibody array, we verified a significant phosphorylation of the up-steam regulators of GSK $3 \beta$, PI-3K (Tyr607), and Akt (Thr72) (Table 2). Further, the antibody array confirmed the significant phosphorylation of GSK-3 $\beta$ (Ser9) and the phosphorylation of the downstream cytokine-activated intracellular signaling pathway involved in stimulating immune

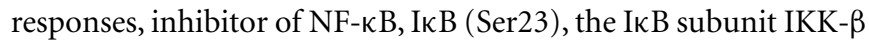
(Tyr188), and the NF- $\mathrm{B}$ subunits p105 (Ser927), p65 (Ser529), and c-Rel (Tyr 1054) (Table 2). Activated IKK- $\beta$ phosphorylates I $\kappa$, which binds NF- $\kappa$ B to inhibit its function. Phosphorylated I $\kappa \mathrm{B}$ is degraded via ubiquitination, thus releasing NF- $\kappa \mathrm{B}$, for entry into the nucleus of the cell where it activates various inflammatory and immune response genes (27).

\section{EFFECT OF GSK-3 $\beta$ ON HETEROPHIL DEGRANULATION}

We verified that stimulation of heterophils with $S$. Enteritidis resulted in increased degranulation in a bacterial

concentration-dependent manner (Figure 4). Interestingly, treating the heterophils with the GSK-3 $\beta$ inhibitor, LiCl, significantly $(p \leq 0.01)$ reduced degranulation to baseline levels.

\section{DISCUSSION}

We and others have shown that the heterophil, as the predominant polymorphonuclear cell in poultry, is the primary innate immune effector cell in the initial response to Salmonella infection (28-32). Heterophils can be found in the lamina propria of the ceca within hours after Salmonella infection $(28,33-36)$ and are reliant more on degranulation to kill bacteria $(37,38)$ than an oxidative burst due to the lack of myeloperoxidase (39). Heterophils have been shown to possess all 10 toll-like receptors identified in the chicken, and they can be functionally activated in vitro with either TLR agonists or intact bacterial cells $(24,25,40-44)$.

We have been investigating the kinase-mediated signaling pathways initiated in heterophils during its interactions with Salmonella $(24-26,44)$, but have not identified the method of regulation of the effector mechanisms within these phagocytic cells. GSK-3 is a multifunctional serine/threonine kinase that has been recently shown to regulate elements of both the innate and acquired 


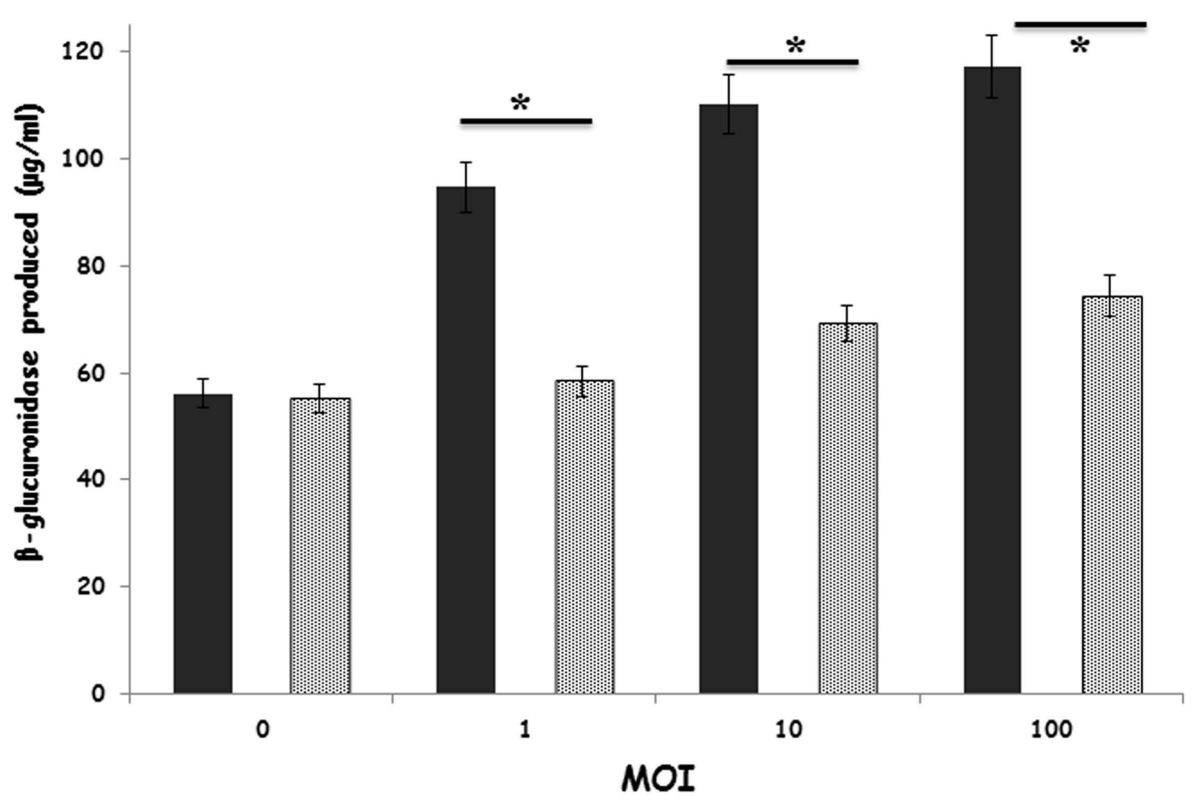

- No $\mathrm{LiCl}$ 四iCl $(10 \mathrm{mM})$

FIGURE 4 | Inhibition of GSK-3 $\beta$ regulates primary degranulation by avian heterophils stimulated with $\boldsymbol{S}$. Enteritidis. Heterophils were pre-incubated with $\mathrm{LiCl}$ for $1 \mathrm{~h}$ and then stimulated with various $\mathrm{MOI}$ of S. Enteritidis for $1 \mathrm{~h}$ at $41^{\circ} \mathrm{C}$. Heterophils $\left(8 \times 10^{6}\right)$ were incubated with either RPMI 1640 medium alone or the GSK inhibitor, $\mathrm{LiCl}$ at room temperature for $1 \mathrm{~h}$. The heterophils were then stimulated with various $\mathrm{MOI}$ of $S$. Enteritidis $(1,10$, or 100$)$ for $1 \mathrm{~h}$ at $41^{\circ} \mathrm{C}$. The reaction was stopped by transferring the tubes containing the cells to an ice bath for 5-10 min. The cells were then centrifuged at $250 \mathrm{~g}$ for $10 \mathrm{~min}$ at $4^{\circ} \mathrm{C}$. The supernatants were then removed and used for the assay. A $25 \mu$ l aliquot of each supernatant was added to quadruplicate wells in a non-treated, black CoStar flat-bottom ELISA plate and incubated with $50 \mu$ l of freshly prepared substrate $10 \mathrm{mM}$ 4-methylumbelliferyl- $\beta$-d-glucuronide, $0.1 \%$ Triton $\mathrm{X}-100$ in $0.1 \mathrm{M}$ sodium acetate buffer) for $4 \mathrm{~h}$ at $41^{\circ} \mathrm{C}$. The reaction was stopped by adding $200 \mu \mathrm{l}$ of stop solution (0.05M glycine and 5 mM EDTA; $\mathrm{pH} 10.4$ ) to each well. Liberated 4-methylumbelliferone was measured fluorimetrically (excitation wavelength of $355 \mathrm{~nm}$ and an emission wavelength of $460 \mathrm{~nm}$ ) with a GENios Plus Fluorescence Microplate Reader (TECAN US Inc., Research Triangle Park, NC, USA). These values were converted to micromoles of 4-methylumbelliferone generated using a standard curve of known concentrations. ${ }^{*} p \leq 0.01$. immune responses $(9,45)$. GSK-3 has two major isoforms $(\alpha$ and $\beta$ ) encoded by two separate genes ( $g s k 3 \alpha$ and $g s k 3 \beta)$ (46) that are structurally very similar, but functionally distinct $(47,48)$. Here, we have characterized the role of GSK-3 $\beta$ in mediating the pro-inflammatory response of heterophils following $S$. Enteritidis infection.

As part of our microarray analysis of $S$. Enteritidis-infected heterophils $(10,11)$, we observed a significant increase in GSK$3 \beta$ transcription within $30 \mathrm{~min}$ that was maintained at $60 \mathrm{~min}$ (Table 1). The differences were also observed at $120 \mathrm{~min}$ (3.01-fold change from uninfected controls, $p<1.72 \times 10^{-8}$ ) and $180 \mathrm{~min}$ (2.69-fold change from uninfected controls, $\left.p<5.37 \times 10^{-8}\right)$. In resting cells, GSK-3 is constitutively active and functions in suppressing multiple cell signaling cascades (49). In the resting cells, GSK-3 forms a complex with the proteins, $\beta$-catenin, and adenomatosis polyposis coli (APC) that inhibits the phosphorylation of $\beta$-catenin, $I \kappa B$, and NF- $\kappa B$ and preventing activation of the pro-inflammatory process $(8,45)$. The increased transcription of GSK-3 $\beta$ in heterophils during their interaction with $S$. Enteritidis implicates its physiological role in the activation of the proinflammatory response to infection. Further data found here confirmed this conclusion (increased expression of pro-inflammatory cytokines, decreased expression of anti-inflammatory cytokines, increased heterophils degranulation).

In response to extracellular stimuli, GSK-3 activity can be regulated by phosphorylation (7). GSK-3 $\beta$ can either be activated by phosphorylation of Tyr216 or inactivated by phosphorylation of Ser9. The results found here determined that increased expression of GSK-3 $\beta$ in response to $S$. Enteritidis resulted in an increase in protein level of total GSK-3 $\beta$ (Figure 1A) and that GSK-3 $\beta$ is phosphorylated at Ser9 (Figure 1B). This site-specific phosphorylation of GSK-3 $\beta$ results in the inactivation of its kinase activity (50). Thus, our data imply that heterophil phagocytosis (28) of Salmonella specifically alters GSK-3 $\beta$ activity by inducing its phosphorylation.

Transcription factors of the NF- $\kappa$ B family remain in a quiescent state, complexed with inhibitory I $\mathrm{B}$ proteins, in the cytosol of virtually all vertebrate cells. Upon activation, I $\mathrm{B}$ proteins are phosphorylated and released from NF- $\kappa \mathrm{B}$, which then undergoes nuclear translocation and initiates gene transcription (27). NF-кB is composed of homo- and heterodimer complexes made from the five subunits of the NF- $\kappa$ B family (p50, p65, p52, c-Rel, and RelB) $(27,51)$. The phosphorylation of $\mathrm{I} \kappa \mathrm{B} \alpha$ following cell activation induces the release of NF- $\mathrm{B}$ dimers, which translocate to 
Table 2 | Antibody array

\begin{tabular}{|c|c|c|}
\hline Protein names & $\begin{array}{l}\text { Fold change in } \\
\text { antibody array }\end{array}$ & $p$ value \\
\hline PI-3K p85 (Phospho-Tyr607) & 1.19439 & 0.007701275 \\
\hline Akt1 (Phospho Thr72) & 1.257975108 & 0.023662291 \\
\hline Akt1 (Phospho-Thr450) & 1.400143780 & 0.008226435 \\
\hline Akt1 (Phospho-Thr246) & 1.83942 & 0.01851747 \\
\hline Akt1 (Phospho-Thr 474) & 1.069000 & 0.046647641 \\
\hline $\begin{array}{l}\text { p70S6 Ribosomal protein } \\
\text { (Phospho-Ser411) }\end{array}$ & -1.058166076 & 0.024709023 \\
\hline $\begin{array}{l}\text { p70S6 Ribosomal protein } \\
\text { (Phospho-Thr 229) }\end{array}$ & -1.198203352 & 0.00514916 \\
\hline Casein kinase 1 (Phospho-Thr321) & 1.021481145 & 0.003365457 \\
\hline GSK-3 $\beta$ (Phospho-Ser9) & 1.753216 & 0.014375 \\
\hline CREB (Phospho 133) & -1.06934158 & 0.015833103 \\
\hline CREB (Phospho-129) & -1.144177379 & 0.01822392 \\
\hline STAT3 (Phospho-Ser727) & -1.046664685 & 0.01141102 \\
\hline STAT5A (Phospho-Tyr694) & -1.354049745 & 0.04702416 \\
\hline STAT6 (Phospho-Tyr641) & -1.378348682 & 0.024248987 \\
\hline ІккB (Phospho-Tyr188) & 1.120064897 & 0.004702625 \\
\hline IкB (Phospho-Ser23) & 1.078084635 & 0.008557762 \\
\hline NF-кB p105 (Phospho-Ser927) & 1.16871 & 0.000567265 \\
\hline NF-кB p65 (Phosphor-Ser 529) & 1.065544284 & 0.012505685 \\
\hline c-Rel (Phospho-Tyr 1054) & 1.250518061 & 0.029025748 \\
\hline$\beta$-catenin (Phospho-Thr41/Ser45) & 1.302534522 & 0.035787183 \\
\hline
\end{tabular}

the nucleus. In our assays as we described previously (18), we found that $S$. Enteritidis stimulation of heterophils activated NF$\kappa \mathrm{B}$, composed of the $\mathrm{p} 50, \mathrm{c}-\mathrm{Rel}$, and/or RelB subunits. However, we cannot rule out the activation of either the p 65 or p52 subunit during chicken heterophils activation due to unavailability of proper reagents to analyze the role of p65 and p52. Furthermore, treating the heterophils with either the I $\mathrm{B}$ phosphorylation inhibitor, BAY 11-7086, or the cell-permeable, inhibitory peptide of the nuclear translocation of NF- $\kappa \mathrm{B}, \mathrm{SN} 50$, prevented the activation of NF- $\kappa \mathrm{B}$ (Figures 3A-C).

GSK-3 $\beta$ - and NF- $\kappa \mathrm{B}$-mediated signaling pathways are directly linked (52). Inactivation of GSK-3 $\beta$ by phosphorylation at Ser9 induced by bacterial infections results in the degradation of $\beta$ catenin, the phosphorylation of IкB by the IKK complex, freeing NF- $\kappa \mathrm{B}$ to translocate to the nucleus (53), which, in turn, leads to an increase expression of pro-inflammatory cytokine genes and release of antimicrobial factors. The results of the present experiments confirm that phosphorylation of GSK-3 $\beta$ (Ser9) results in the activation of NF- $\kappa$ B (Figures $3 \mathrm{~A}-\mathrm{C}$ ). The role of GSK-3 $\beta$ as a mediator of NF- $\kappa \mathrm{B}$ activation was shown by the total inhibition of NF- $\kappa B$ subunit activation by the specific GSK- $3 \beta$ inhibitor, lithium (Figures 3A-C).

As expected and found in previous studies, $S$. Enteritidis infection induced the upregulation of pro-inflammatory cytokines, specifically in these experiments IL-6 (Figure 2A). GSK-3 $\beta$ inactivation using lithium augmented anti-inflammatory cytokine production (IL-10) while concurrently suppressing the production of pro-inflammatory cytokines (Figures 2A,B). Similar results have been described with a number of viral and bacterial infections including Venezuelan Equine encephalitis virus, Franicisella tularensis, Burkholderia psuedomallei, and S. Typhimurium $(51,53-56)$. It is evident that GSK-3 $\beta$ plays a crucial regulatory role in controlling the quality and extent of the cytokine response to a number of bacterial infections in different hosts. Tay and colleagues (54) have described this as a "distinct survival advantage" for the host during an infection since the event controls the "cytokine storm" that can be initiated and mediated by bacteria during an acute infection as a strategy to favor their own survival $(57,58)$. Further experiments will be needed to determine whether GSK-3 $\beta$ can be modulated to influence susceptibility to infection in chickens.

By using an antibody microarray containing both pan-specific and phospho-specific antibodies instead of western blots, we were able to quantify the phosphorylation events induced in the GSK$3 \beta$ signaling cascade (Table 2). A number of interesting responses were found by using the phosphor-specific antibody array. First, we confirmed that infection of $S$. Enteritidis by the heterophils induced the phosphorylation of GSK-3 $\beta$ at Ser9. In addition, we showed the phosphorylation of I $\mathrm{B}$ complex, and phosphorylation of multiple subunits of NF- $\kappa \mathrm{B}$ confirming activation demonstrated with the NF- $\kappa$ B activation assays (Figures $3 \mathrm{~A}-\mathrm{C}$ ). Second, the antibody array provides data that PI3K/Akt signaling inac-

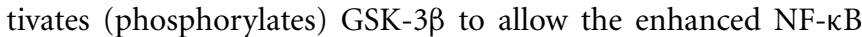
activity resulting in the increased expression of pro-inflammatory cytokines in heterophils following infection with $S$. Enteritidis. Similar results have been reported in macrophages infected with the gram-negative respiratory bacterium, Burkholderia cenocepacia (55). We have previously shown that receptor-mediated phagocytosis of $S$. Enteritidis by heterophils activated PI-3K and Akt (24-26). The antibody array data provide new information on the downstream events by which PI3K/Akt modulates heterophils effector function through inactivation of GSK-3 $\beta$ and enhances NF- $\kappa \mathrm{B}$ activity. Third, the inactivation of GSK-3 $\beta$ by phosphorylation at Ser9 positively regulated NF- $\kappa \mathrm{B}$ activity, but, based on the antibody array data, negatively regulated the transcription factors, cAMP-response element-binding protein (CREB), and signal-transducer and activator of transcription (STAT3, 5A, and 6). These results imply that the phosphorylation of GSK-3 $\beta$ in heterophils differentially regulate transcription factor activity. This differential regulatory activity on transcription factor activation has previously been reported in human monocytes stimulated with TLR agonists (59). Activation of STAT3 and STAT5 are dependent on GSK-3 activation (60), so inactivation of GSK-3 $\beta$ by phosphorylation inactivates STAT 3 and STAT5 as observed here. Fourth, results from the antibody array showed the dephosphorylation of the target of mTORC1, p70S6 ribosomal protein. These results have been reported in monocytes stimulated with LPS, where mTORC1 regulates GSK-3 $\beta$ activity through the activation of the p70 S6 ribosomal protein (45). Inhibition of S6 ribosomal protein phosphorylation blocks GSK-3 $\beta$ activity resulting in increased pro-inflammatory and decreased anti-inflammatory activities (45). The results from the antibody array are suggestive of a similar mechanism at play in the $S$. Enteritidis-infected heterophils. Finally, we measured an increase in phosphorylation of $\beta$ catenin, a transcription factor that regulates cell proliferation and 
inflammation (53). $\beta$-catenin is a negative regulator of inflammation acting in a manner similar to I $\mathrm{B}$ in physically binding to NF$\kappa \mathrm{B}$, thereby preventing its activation $(53,61,62)$. S. Typhimurium intestinal infection in a murine model induces the phosphorylation of GSK-3 $\beta$ which, in turn, induces the phosphorylation of $\beta$-catenin and results in the translocation of NF- $\kappa \mathrm{B}$ to the nuclease (53). Based on the results presented here, we speculate that a similar series of events occurs in the $S$. Enteritidis-infected heterophils resulting in the increased expression of pro-inflammatory cytokines and release of pro-inflammatory effector mediators (degranulation). Although further experiments are required to prove this mechanism of heterophils activation, it is reasonable to believe that based on the results found here that this speculation is accurate.

In summary, we have demonstrated a role for GSK-3 $\beta$ in mediating a pro-inflammatory response in chicken heterophils to infection with $S$. Enteritidis. Our data revealed that the phosphorylation of GSK-3 $\beta$ (Ser9) is responsible for inducing and controlling an innate response to the bacteria. We have identified how GSK-3 $\beta$ regulates the pro-inflammatory reactions of heterophils in response to a Salmonella infection and characterized the molecular interactions central to this response. Our findings suggest that the repression of GSK-3 activity is beneficial to the host cell and may act as a target for treatment in controlling intestinal colonization in chickens. Further experiments will define the in vivo modulation of GSK-3 as a potential alternative to antibiotics in salmonella and other intestinal bacterial infections.

\section{REFERENCES}

1. Genovese KJ, He H, Swaggerty CL, Kogut MH. The avian heterophils. Dev Comp Immunol (2013) 41:334-40. doi:10.1016/j.dci.2013.03.021

2. Wathanage GS, Kaiser P, Wigley P, Powers C, Mastroeni P, Brooks H, et al. Rapid expression of chemokines and pro-inflammatory cytokines in newly hatched chickens infected with Salmonella enterica serovar Typhimurium. Infect Immun (2004) 72:2152-9. doi:10.1128/IAI.72.4.2152-2159.2004

3. Kogut MH, Iqbal M, He H, Philbin V, Kaiser P, Smith A. Expression and function of toll-like receptors in chicken heterophils. Dev Comp Immunol (2005) 29:791-807. doi:10.1016/j.dci.2005.02.002

4. Swaggerty CL, Ferro PJ, Pevzner IY, Kogut MH. Heterophils are associated with resistance to systemic Salmonella enteritidis infection in genetically distinct lines of chickens. FEMS Immunol Med Microbiol (2005) 43:149-54. doi:10.1016/j.femsim.2004.07.013

5. Cortes-Vieya R, Bravo-Patino A, Valdez-Alarcon JJ, Juarez MC, Finlay BB, Balzabal-Aquirre VM. Role of glycogen synthase kinase- 3 beta in the inflammatory response caused by bacterial pathogens. J Inflamm (2012) 9:23. doi:10. 1186/1476-9255-9-23

6. Giambelluca MS, Cloutier N, Rollet-Labelle E, Boilard E, Pouliot M. Expression and regulation of glycogen synthase 3 in human neutrophils. Int J Biochem Cell Biol (2013) 45:2660-5. doi:10.1016/j.biocel.2013.09.001

7. Doble BW, Woodgett JR. GSK-3, tricks of the trade for a multi-tasking kinase. J Cell Sci (2003) 116:1175-86. doi:10.1242/jcs.00384

8. Jope RS, Johnson GV. The glamour and gloom of glycogen synthase kinase-3. Trends Biochem Sci (2004) 29:95-102. doi:10.1016/j.tibs.2003.12.004

9. Beurel E, Michalek SM, Jope RS. Innate and adaptive immune responses regulated by glycogen synthase kinase-3 (GSK3). Trends Immunol (2010) 31:24-31. doi:10.1016/j.it.2009.09.007

10. Chiang HI, Swaggerty CL, Kogut MH, Dowd SE, Li X, Pevzner IY, et al. Gene expression profiling in chicken heterophils with Salmonella enteritidis stimulation using a chicken $44 \mathrm{~K}$ agilent microarray. BMC Genomics (2008) 9:526. doi:10.1186/1471-2164-9-526

11. Kogut MH, Chiang HI, Swaggerty CL, Pevzner IY, Zhou H. Gene expression analysis of toll-like receptor pathways in heterophils from genetic chicken lines that differ in their susceptibility to Salmonella enteritidis. Front Genet (2012) 3:121. doi:10.3389/fgene.2012.00121

12. National Research Council. Nutritional Requirements of Poultry. 9th ed. Washington, DC: National Academy Press (1994).

13. Kogut MH, He H, Genovese KJ, Jiang YW. Feeding the BT cationic peptides to chickens at hatch reduces cecal colonization by Salmonella enterica serovar Enteritidis and primes innate immune cell functional activity. Foodborne Pathog Dis (2010) 7:23-30. doi:10.1089/fpd.2009.0346

14. Kogut MH, Genovese KJ, He H, Swaggerty CL, Jiang YW. BT cationic peptides: small peptides that modulate innate immune responses of chicken heterophils and monocytes. Vet Immunol Immunopathol (2012) 145:151-8. doi:10.1016/j.vetimm.2011.10.023

15. Storey JD, Tibshirani R. Statistical significance for genome wide studies. Proc Natl Acad Sci U S A (2003) 1000:9440-5. doi:10.1073/pnas.1530509100

16. Li Y, Arsenault RJ, Trost B, Slind J, Griebel PJ, Napper S, et al. A systematic approach for analysis of peptide array kinome data. Sci Signal (2012) 5:12. doi:10.1126/scisignal.2002429

17. Szklarczyk D, Franceschini A, Kuhn M, Simonovic M, Roth A, Minguez P, et al. The STRING database in 2011: functional interaction networks of proteins, globally integrated and scored. Nucleic Acids Res (2011) 39(Suppl 1):D561-8. doi:10.1093/nar/gkq973

18. Kogut MH, Genovese KJ, He H, Kaiser P. Flagellin and lipopolysaccharide upregulation of IL- 6 and CXCLi2 gene expression in chicken heterophils is mediated by ERK1/2-dependent activation of AP-1 and NF-kappaB signaling pathways. Innate Immun (2008) 14:213-22. doi:10.1177/1753425908094416

19. Kaiser P, Rothwell L, Galyov EE, Barrow PA, Burnside J, Wigley P. Differential cytokine expression in avian cells in response to invasion by Salmonella typhimurium, Salmonella enteritidis and Salmonella gallinarum. Microbiology (2000) 146:3217-26.

20. Kogut MH, Rothwell L, Kaiser P. Differential regulation of cytokine gene expression by avian heterophils during receptor-mediated phagocytosis of opsonized and nonopsonized Salmonella enteritidis. I Interferon Cytokine Res (2003) 23:319-27. doi:10.1089/107999003766628160

21. Zeng L, Fagotto F, Zhang T, Hsu W, Vasicek TJ, Perry WL, et al. The mouse fused locus encodes axin, an inhibitor of the Wnt signaling pathway that regulates embryonic axis formation. Cell (1997) 90:181-92. doi:10.1016/S0092-8674(00) 80324-4

22. Logan CY, Nussse R. The Wnt signaling pathway in development and disease. Annu Rev Cell Dev Biol (2004) 20:781-810. doi:10.1146/annurev.cellbio. 20.010403.113126

23. Luo W, Ng WW, Jin LM, Ye Z, Han J, Lin SC. Axin utilizes distinct regions for competitive MEKK and MEKK4 binding and JNK activation. J Biol Chem (2003) 278:37451-8. doi:10.1074/jbc.M305277200

24. Kogut MH, Lowry VK, Farnell M. Selective pharmacological inhibitors reveal the role for Syk tyrosine kinase, phopholipase C, and phophotidylinositol-3-kinase and p38 mitogen-activated protein kinase in Fc receptor-mediated signaling of chicken heterophil degranulation. Int Immunopharmacol (2002) 2:963-73. doi:10.1016/S1567-5769(02)00050-4

25. Farnell MB, He H, Genovese KJ, Kogut MH. Pharmacological analysis of signal transduction pathways required for oxidative burst in chicken heterophils stimulated by a Toll-like receptor 2 agonist. Int Immunopharamacol (2003) 3:1677-84 doi:10.1016/S1567-5769(03)00205-4

26. He H, Genovese KJ, Nisbet DJ, Kogut MH. Phospholipase C, phosphoinositol 3-kinase, and intracellular $\left[\mathrm{Ca}^{2+}\right]$, mediate the activation of chicken HD11 macrophage cells by CpG oligodeoxynucleotide. Dev Comp Immunol (2008) 32:1111-8. doi:10.1016/j.dci.2008.02.009

27. Ghosh S, May MJ, Kopp EB. NF-кB and Rel proteins: evolutionarily conserved mediators of immune responses. Annu Rev Immunol (1999) 16:225-60. doi:10.1146/annurev.immunol.16.1.225

28. Kogut MH, McGruder ED, Hargis BM, Corrier DE, DeLoach JR. Dynamics of the avian inflammatory response to Salmonella-immune lymphokines. Changes in avian blood leukocyte populations. Inflammation (1994) 18:373-88. doi:10.1007/BF01534435

29. Swaggerty CL, Kogut MH, Ferro PJ, Rothwell L, Pevzner IY, Kaiser P. Differential cytokine mRNA expression in heterophils isolated from Salmonella-resistant and -susceptible chickens. Immunology (2004) 113:139-48. doi:10.1111/j.13652567.2004.01939.x

30. Van Immerseel F, Methner U, Rychlik I, Nagy B, Velge P, Martin G, et al. Vaccination and early protection against non-host-specific Salmonella serotypes in 
poultry: exploitation of innate immunity and microbial activity. Epidemiol Infect (2005) 133:959-78. doi:10.1017/S0950268805004711

31. Methner U, Barrow PA, Berndt A. Induction of homologous and heterologous invasion-inhibition effect after administration of Salmonella strains to newly hatched chicks. Vaccine (2010) 28:6958-63. doi:10.1016/j.vaccine.2010. 08.050

32. Redmond SB, Chuammitri P, Andreasen CB, Palic D, Lamont SJ. Genetic control of chicken heterophil function in advanced intercross lines: associations with novel and with known Salmonella resistance loci and a likely mechanism for cell death in extracellular trap production. Immunogenetics (2011) 63:449-58. doi:10.1007/s00251-011-0523-y

33. Setta AM, Barrow PA, Kaiser P, Jones MA. Early immune dynamics following infection with Salmonella enterica serovars Enteritidis, Infantis, Pullorum, and Gallinarum: cytokine and chemokine gene expression profile and cellular changes of chicken cecal tonsils. Comp Immunol Microbiol Infect Dis (2012) 35:397-410. doi:10.1016/j.cimid.2012.03.004

34. Van Immerseel F, DeBuck J, DeSmet I, Haesebrouck F, Ducatelle R. Dynamics of immune cell infiltration in the cecal lamina propria of chickens after neonatal infection with a Salmonella Enteritidis strain. Dev Comp Immunol (2002) 26:355-64. doi:10.1016/S0145-305X(01)00084-2

35. Van Immerseel F, DeBuck J, DeSmet I, Haesebrouck F, Ducatelle R. The effect of vaccination with a Salmonella Enteritidis aroA mutant on early cellular responses in cecal lamina propria. Vaccine (2002) 20:3034-41. doi:10.1016/ S0264-410X(02)00227-X

36. Berndt A, Muller J, Borsi L, Kosmenhl H, Methner U, Berndt A. Reorganization of the cecal extracellular matrix upon Salmonella infection - relation between bacterial invasiveness and expression of virulence genes. Vet Microbiol (2009) 133:123-37. doi:10.1016/j.vetmic.2008.06.025

37. Kogut MH, Lowry VK, Farnell M. The use of selective pharmacological inhibitors to delineate signal transduction pathways activated during complement receptor-mediated degranulation in chicken heterophils. Int Immunopharmacol (2003) 3:693-706. doi:10.1016/S1567-5769(03)00057-2

38. He H, Genovese KJ, Swaggerty CL, Nisbet DJ, Kogut MH. In vivo priming heterophil innate immune functions and increasing resistance to Salmonella enteritidis infection in neonatal chickens by immune stimulatory CpG oligo-deoxynucleotides. Vet Immunol Immunopathol (2007) 117:275-83. doi:10.1016/j.vetimm.2007.03.002

39. Brune K, Leffell MS, Spitznagel JK. Microbicidal activity of peroxidase less chicken heterophil leukocytes. Infect Immun (1972) 5:283-7.

40. Kogut MH, Igbal M, He H, Philbin V, Kaiser P, Smith A. Expression and function of toll-like receptors in chicken heterophils. Dev Comp Immunol (2005) 29:791-807. doi:10.1016/j.dci.2005.02.002

41. Kogut MH, Swaggerty C, He H, Pevzner I, Kaiser P. Toll-like receptor agonists stimulate differential functional activation and cytokine and chemokine gene expression in heterophils isolated from chickens with differential innate response. Microbes Infect (2006) 8:1866-74. doi:10.1016/j.micinf.2006. 02.026

42. Nerren JR, Swaggerty CL, MacKinnon KM, Genovese KJ, He H, Pevzner I, et al. Differential mRNA expression of avian-specific toll-like receptor 15 between heterophils from Salmonella-susceptible and -resistant chickens. Immunogenetics (2009) 61:71-7. doi:10.1007/s00251-008-0340-0

43. Nerren JR, Kogut MH. The selective Dectin-1 agonist curdlan, induces an oxidative burst response in chicken heterophils and peripheral blood mononuclear cells. Vet Immunol Imunopathol (2010) 127:162-6. doi:10.1016/j.vetimm.2008. 09.011

44. Swaggerty CL, He H, Genovese J, Pevzner IY, Kogut MH. Protein tyrosine kinase and mitogen-activated protein kinase signaling pathways contribute to differences in heterophIL-mediated innate immune responsiveness between two lines of broilers. Avian Pathol (2011) 40:289-97. doi:10.1080/03079457.2011.565310

45. Wang H, Brown J, Gu Z, Garcia CA, Liang R, Alard P, et al. Convergence of the mammalian target of rapamycin complex 1-and glycogen synthase kinase 3 - $\beta$-signaling pathways regulates the innate inflammatory response. J Immunol (2011) 186:5217-26. doi:10.4049/jimmunol.1002513

46. Ali A, Hoeflich KP, Woodgett JR. Glycogen synthase kinase-3: properties, functions, and regulation. Chem Rev (2001) 101:2527-40. doi:10.1021/cr000110o

47. Woodgett JR. Molecular cloning and expression of glycogen synthase kinae3/factor A. EMBO J (1990) 9:2431-8.

48. Hoeflich KP, Luo J, Rubie EA, Tsao MS, Jin O, Woodgett JR. Requirement for glycogen synthase kinase-3 beat in cell survival and NF-kappaB activation. Nature (2000) 406:86-90. doi:10.1038/35017574
49. Woodgett JR. Regulation and functions of the glycogen synthase kinase-3 subfamily. Semin Cancer Biol (1994) 5:269-75.

50. Cross DA, Alessi DR, Cohen P, Andjelkovich M, Hemmings BA. Inhibition of glycogen synthase kinase- 3 by insulin mediated by protein kinase B. Nature (1995) 178:785-9. doi:10.1038/378785a0

51. Zhang P, Katz J, Michalek SM. Glycogen synthase kinase-3 $\beta$ (GSK3 $\beta$ ) inhibition suppresses the inflammatory response to Francisella infection and protects against tularemia in mice. Mol Immunol (2009) 46:677-87. doi:10.1016/j. molimm.2008.08.281

52. Stenbrecher KA, Wilson W, Cogswell PC, Baldwin AS. Glycogen synthase kinase $3 \beta$ functions to specify gene-specific, NF-кB-dependent transcription. Mol Cell Biol (2005) 25:8444-55. doi:10.1128/MCB.25.19.8444-8455.2005

53. Duan Y, Liao AP, Kuppireddi S, Ye Z, Ciancio MJ, Sun J. $\beta$-Catenin activity negatively regulates bacteria-induced inflammation. Lab Invest (2007) 87:613-24. doi:10.1038/labinvest.3700545

54. Tay TF, Maheran M, Too SL, Hasidah MS, Ismail G, Embi N. Glycogen synthase kinase $-3 \beta$ inhibition improved survivability of mice infected with Burkholderia pseudomallei. Trop Biomed (2012) 29:551-67.

55. Cremer TJ, Shah P, Cormet-Boyaka E, Valvano MA, Butchar JP, Tridandapani S. Akt-mediated pro-inflammatory response of mononuclear phagocytes infected with Burkholderia cenocepacia occurs by a novel GSK3 $\beta$-dependent, IКB kinase-independent mechanism. J Immunol (2011) 187:635-43. doi:10.4049/ jimmunol.1003034

56. Kehn-Hall K, Narayanan A, Lunberg L, Sampey G, Pinkham C, Van Duyne R, et al. Modulation of GSK-3 $\beta$ activity in Venezuelan equine encephalitis virus infection. PLoS One (2012) 7:e34761. doi:10.1371/journal.pone.0034761

57. Finlay BB, McFadden G. Anti-immunology: evasion of the host immune system by bacterial and viral pathogens. Cell (2006) 124:767-82. doi:10.1016/j.cell. 2006.01.034

58. Mares CA, Ojeda SS, Morris EG, Li Q, Teale JM. Initial delay in the immune responses to Francisella tularensis is followed by hypercytokinemia characteristic of severe sepsis and correlating with up-regulation and release of damageassociated molecular patterns. Infect Immun (2008) 76:3001-10. doi:10.1128/ IAI.00215-08

59. Martin M, Rehani K, Jope RS, Michael SM. Toll-like receptor-mediated cytokine production is differentially regulated by glycogen synthase kinase-3. Nat Immunol (2005) 6:777-84. doi:10.1038/ni1221

60. Beurel E, Jope RS. Differential regulation of STAT family members by glycogen synthase kinase-3. J Biol Chem (2008) 283:21934-44. doi:10.1074/jbc. M802481200

61. Liu X, Lu R, Wu S, Zhang Y-G, Xia Y, Sartor RB, et al. Wnt2 inhibits enteric bacterial-induced inflammation in intestinal epithelial cells. Inflamm Bowel Dis (2012) 18:418-29. doi:10.1002/ibd.21788

62. Matsusaka T, Fujikawa K, Nishio Y, Mukaida N, Matsushima K, Kishimoto T, et al. Transcription factors NF-IL6 and NF-kappa B synergistically activate transcription of the inflammatory cytokines, interleukin-6 and interleukin 8. Proc Natl Acad Sci U S A (1993) 90:10193-7. doi:10.1073/pnas.90.21.10193

Conflict of Interest Statement: The authors declare that the research was conducted in the absence of any commercial or financial relationships that could be construed as a potential conflict of interest. The Review Editor Vivek A. Kuttappan declares that, despite having collaborated with author Michael Kogut in the past 2 years, the review process was handled objectively. The Review Editor Amanda Wolfenden declares that, despite having collaborated with author Michael Kogut, the review process was handled objectively.

Received: 09 May 2014; paper pending published: 28 June 2014; accepted: 29 September 2014; published online: 24 November 2014

Citation: Kogut MH, Swaggerty CL, Chiang H-I, Genovese KJ, He H, Zhou H and Arsenault $R J$ (2014) Critical role of glycogen synthase kinase- $3 \beta$ in regulating the avian heterophil response to Salmonella enterica serovar Enteritidis. Front. Vet. Sci. 1:10. doi: 10.3389/fvets.2014.00010

This article was submitted to Veterinary Infectious Diseases, a section of the journal Frontiers in Veterinary Science.

Copyright (C) 2014 Kogut, Swaggerty, Chiang, Genovese, He, Zhou and Arsenault. This is an open-access article distributed under the terms of the Creative Commons Attribution License (CC BY). The use, distribution or reproduction in other forums is permitted, provided the original author(s) or licensor are credited and that the original publication in this journal is cited, in accordance with accepted academic practice. No use, distribution or reproduction is permitted which does not comply with these terms. 